\title{
Do not question my honour: A social-scientific reading of the parable of the minas (Lk 19:12b-24, 27)
}

\begin{abstract}
Author:
Ernest van Eck ${ }^{1}$

Affiliation:

${ }^{1}$ Department of New

Testament Studies, University

of Pretoria, South Africa

Note:

This article was initially presented as a paper at the International Meeting of the Context Group that was held on 03-05 August 2010 at the University of Pretoria, South Africa.
\end{abstract}

\section{Correspondence to:}

Ernest van Eck

Email:

ernest.vaneck@up.ac.za

\section{Postal address:}

Department of New

Testament Studies, Faculty of Theology, University of

Pretoria, Lynwood Road

Hatfield 0083, South Africa

\section{Dates:}

Received: 16 Nov. 2010

Accepted: 29 Nov. 2010

Published: 03 Oct. 2011

How to cite this article: Van Eck, E., 2011, 'Do not question my honour: $\mathrm{A}$ social-scientific reading of the parable of the minas (Lk 19:12b-24, 27)', HTS Teologiese Studies/ Theological Studies 67(3), Art. \#977, 11 pages. doi:10.4102/hts.v67i3.977

(C) 2011. The Authors. Licensee: AOSIS OpenJournals. This work is licensed under the Creative Commons Attribution License.
This article attempted to read the parable of the minas in a $30 \mathrm{CE}$ context, employing a social scientific reading. The integrity of the parable was delimited to Luke 19:12b-24 and 27. It was argued that this version of the parable (that stems from $Q$ ) goes back to the earliest layer of the historical Jesus tradition and is a realistic version of the historical background, political background and socioeconomic background of 30 CE Palestine. In this reading of the parable, attention was given to an aspect much neglected in previous scholarship regarding the interpretation of the parable, namely that the third slave in the parable is not condemned. It was argued that this neglected aspect is important for the strategy of the parable. The reading concluded that the parable has two foci; it shows how, in the time of Jesus, the elite exploited the nonelite and how to protest in a situation where the peasantry (the exploited) had no legitimate way of protesting against the exploitative practices of the elite.

\section{Introduction}

This article attempts a reading of the parable of the minas within the 30 CE context of Jesus the Galilean (the historical Jesus), employing a social-scientific approach. This point of departure implies, as Jülicher (1910:11) has indicated, that the authenticity of the parable (as presented in Matthew 25:14-30 and Luke 19:12-27) cannot simply be assumed. The parables in the Synoptics have been translated, transposed and transformed and vary in terms of viewpoint, arrangement, occasion and interpretation. This is clearly visible in the differences between the Mattheanversions and Lukan-versions in the Synoptic tradition (as will be discussed further). The parable of the talents or minas existed prior to its incorporation into Matthew and Luke, implying that the voice of Jesus can only be identified through critical analysis in the voices of Matthew and Luke (Jülicher 1910:11; see Van Eck 2009:310-311). The choice for a social-scientific approach relates to the fallacy of ethnocentrism (and anachronism). ${ }^{1}$ In an effort to avoid this fallacy, an understanding of the cultural values and social dynamics of the social world of Jesus and his hearers is deemed an absolute necessity. To help us, as modern readers, to gain some understanding of the social world of Jesus, social-scientific criticism presents itself as the obvious line of approach.

In what follows, attention will firstly be given to the different versions of the parable in the Synoptics. It is argued that the versions of the parable in Matthew and Luke stem from Q. Luke 19:12b-24 and 27 most probably represents the earliest layer of the parable (or at least, the closest we can get to the earliest layer of the historical Jesus), whilst Matthew reworked the Q-parable to fit his eschatological agenda. Subsequently, the history of the parable's interpretation is attended to, including the few social-scientific readings of the parable performed thus far. It is indicated that the social-scientific interpretation of the parable differs from all other interpretations in that it interprets the actions of the third slave in a positive light. Attention is given to the integrity of the parable in the subsequent section, delimiting it to Luke 19:12b-24 and 27, thus including the so-called 'throne claimant parable' (Lk 19:12b, 14 and 27). This inclusion is substantiated in what follows, where it is indicated that the inclusion of Luke 19:12b, 14 and 27 makes it possible to read the parable as a realistic version of the historical background, political background and socioeconomic background of 30 CE Palestine. Finally, the parable is read from a social-scientific perspective, taking into consideration its situation and strategy. The social-scientific reading makes use of especially the work of Rohrbaugh (1993:32-39).

\section{Which version?}

The parable of the talents or minas is found in Matthew 25:14-30, Luke 19:12b-27 and in the gospel of the Nazoreans $18^{2}$ (as recorded by Eusebius, De Theophania 4.22 [on Matthew 25:14-15]).

1.An anachronistic and ethnocentristic reading of the parables entails a reading that reads 'into the text information from some present social context rather than comprehending the text in accord with its own contemporary social and cultural scripts' (Elliott 1993:11).

2.'(18) But since the Gospel (written) in Hebrew characters which has come into our hands enters the threat not against the man who hid (the talent), but against him who had lived dissolutely - for he (the master) had three servants: one who squandered his master's substance with harlots and flute-girls, one who multiplied the grain, and one who hid the talent; and accordingly one was accepted (with joy), another merely rebuked, and another cast in prison - I wonder whether in Matthew the threat which is uttered after the word against the man who did nothing may refer not to him, but by epanalepsis to the first who had feasted and drunk with the drunken' (translation in Funk, Scott \& Butts 1988:55). 
Which of these versions of the parable most probably goes back to the earliest layer of the Jesus-tradition?

Most scholars view the Nazorean-version of the parable as a later re-interpretation of Matthew's version of the parable. According to this version, the first servant squanders the money on prostitutes, the second increases the amount and the third hides the money in the ground. These actions result in three outcomes; the first servant is accepted, the second is rebuked and the third is thrown into prison. ${ }^{3}$ Jeremias (1972:58), for example, calls it a 'moralistic perversion which the parable has undergone in the Jewish-Christian church'; the early church most probably took offence at the judgement passed on the third servant (see Mt 25:30) and, on the basis of texts like Luke 12:45 and 15:30, substituted extravagance for unfaithfulness. The early church thus 'corrected' (moralised) this point of Matthew's parable (see also Dodd 1961:120; Lambrecht 1983:183; Wohlgemut 1997:111). The Nazoreanversion of the parable can therefore be dismissed as a possible starting point if one is interested in the version of the parable that most probably goes back to the earliest layer of the Jesustradition.

With regard to the Matthean and Lukan versions of the parable, Herzog (1994:15) correctly states that the differences between these two versions are significant enough 'to raise the question ... whether they are different versions of a common source or distinctive variations on a common theme'. This question has been answered in many different ways by as many scholars. Some scholars argue that both versions stem from Q (see e.g. Buttrick 2000:171-177; Donahue 1988:105; Funk, Hoover \& The Jesus Seminar 1993:255; Lambrecht 1983:167; Münch 2007:240-254; Weder 1984:193), whilst others are of the opinion that the differences between the two version indicate that they stem from special Matthean (M) and Lukan (L) traditions (i.e. Sondergut; Boucher 1981:139; Crossan 1973:98; Dodd 1961:114; Jeremias 1972:59-60; Manson 1951:245; Snodgrass 2008:525, 529-531; Weiser 1971:256; Wohlgemut 1997:105). Other possibilities postulated are that the two parables stem from a preSynoptic eschatological discourse concluding with several parables, one of which was the parable of the talents or minas (Wenham 1984:52,101); that both versions of the parable are original and was told by Jesus at two different occasions (Blomberg 1990:220; Capon 1989:78; Groenewald 1973:224; Kistemaker 1980:12; Oesterley 1936:143-144); and that the Matthean and Lukan versions go back to the same original parable (not Q; Boucher 1981:139). ${ }^{4}$ In an effort to unravel the tradition history of the parable, some scholars have tried to construct an 'original parable' (see e.g. Crossan 1973:100; Herzog 1995:155; Lambrecht 1983:165-195; Scott 1989:218215; Weder 1984:202-203; Weiser 1971:230-231, 237, 247; Wohlgemut 1997:103-120), whilst others have suggested that the different versions in Matthew and Luke should at least (at the very least) be attributed to some 'original' form (Dodd

3.See, however, Rohrbaugh (1993:32-39) and Herzog (1989:152) in what follows for different interpretation of this version of the parable.

4.See Kloppenborg (1988:200) for a detailed discussion and bibliography of the different possibilities regarding the origin and relationship between the Matthean and Lukan versions of the parable.
1961:117; Jeremias 1972:61-62; Jülicher 1910:482; Manson 1951:245; Smith 1937:168; Via 1972:115).

Most scholars render the Matthean version as the one closest to the original, but at the same time are of the opinion that it contains secondary features that makes Matthew 25:14-30 an apocalyptic eschatological version of a possible original Jesus parable $^{5}$ (see e.g. Buttrick 2000:173; Funk et al. 1988:55; Herzog 1994:155; Hultgren 2000:279; Jeremias 1972:60; Scott 1989:223; Smith 1973:162; Wohlgemut 1997:106; Young 1989:168).

In this regard, the following eschatological features of Matthew 25:14-30 can be indicated:

- the parable is part of Matthew's apocalyptic discourse of judgement (Mt 24-25) that emphasises the need for faithful activity whilst the second coming is delayed (Scott 1989:219; Donahue 1988:108; Hultgren 2000:274; Lambrecht 1970:312-313; Perkins 1981:146)

- it is a conclusion to a triad of eschatological parables in Matthew 25 (Mt 24:45-51 [the parable of the wise and faithful slave]; Mt 25:1-13 [the parable of the ten maidens; and Mt 25:14-30 [the parable of the talents]; see Reid 2001:202)

- the introductory formula ( to the parable of the ten maidens (Mt 25:1-13) that is apocalyptic eschatological in content (Herzog 1994:151; Hultgren 2000:274; Oesterley 1936:143; Snodgrass 2008:526; Weder 1984:194)

- Matthew 25:30 turns the kupíous [master] into an eschatological judge (Via 1967:114), the kurios of the Christian community (Hultgren 2000:278; Snodgrass 2008:526)

- the parable has as basic topic the delay and the certainty of the parousia, as well as the responsibility (proper action) in the face of absent masters (Donahue 1988:108, 109; Hultgren 2000:274; Buttrick 2000:172)

- the parable is congenial to Matthew's view of the Matthean community as a community of which some are not suitable for the final joy at the end of time ${ }^{6}$ (Funk, Scott \& Butts 1988:67).

When compared to Luke's version, Matthews' apocalyptic eschatological application of the parable can also be detected in his redactional activity:

5.See, for example, Jeremias (1972:60) and Herzog (1994:155): Matthew has preserved the earliest version of the parable, 'although even here [Matthew's version] secondary features are to be observed' (Jeremias 1972:60) and Matthew 25:14b-28 should be seen as 'the working version of the parable attributed to Jesus' (Herzog 1994:155). There is an anomaly to be detected in Hertzog's argument here. In taking Matthew 25:14b-28 as the working version of the parable that can be attributed to Jesus, Herzog includes Matthew 25:15b, 19, 21 and 23 (aspects of the parable that have clear eschatological overtones) as part of the parable attributed to Jesus. In essence, Herzog, in this decision, denies his own understanding of the stages of the tradition of the parable, namely that the eschatological application of the parable should be seen as the final stage of its transitional development. Interesting also is that Herzog makes use of certain aspects of Luke's version of the parable ( $\varepsilon$ u

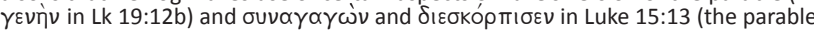
of the prodigal son) to read the Matthean version of the parable respectively against the background of an urban aristocratic household and to argue that the first two retainers monetised the wheat that the peasant farmers winnowed on behalf of retainers monetised the wheat that the peasant farmers winnowed on behalf of their patron (see Herzog 1994:158, 194). If the eschatological application of the overtones in Matthew 25:15b, 19, 21 and 23 simply cannot be part of a 'working Overtones in Matthew $25: 15 \mathrm{~b}, 19,21$ and
version' of the parable attributed to Jesus.

6.See also Matthew 13:24b-43a (the parable of the planted weeds), Matthew 13:4750 (the parable of the dragnet) and Matthew 22:2-14 (the parable of the great banquet) that have the same theme, namely separation of the good and the bad. 
- the kúpıos only returns ' $\mu \varepsilon \tau \alpha \grave{~} \delta \varepsilon \dot{\varepsilon} \pi 0 \lambda u ̛ v$ Xpóvov' [after a long time], a reference to the delay of the parousia (Buttrick 2000:172; Hultgren 2000:278; McGaughy 1975:237; Wohlgemut 1997:108)

- the first two slaves are rewarded for what they achieved

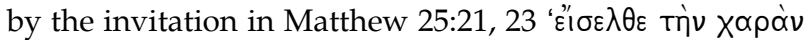
Toû kupíou бou' [enter into the joy of the master], which refers to the messianic eschatological banquet (Buttrick 2000:172; Hultgren 2000:277-278; Jeremias 1972:60; Lambrecht 1983:178; McGaughy 1975:237; Via 1967:114; Wohlgemut 1997:108)

- the addition of Matthew 25:30 (the judgement of the third slave) refers to Matthew's apocalyptic discourse of judgement (Hultgren 2000:278; Wohlgemut 1997:106; Via 1967:114; Wohlgemut 1997:108; Lambrecht 1983:178; see also Mt 8:12; 13:42, 50; 22:13; 24:51).

According to Donahue (1988:108-109), the following features of Matthew's version are also typically Matthean:

- the description of events in grand scale (the use of $\tau \alpha$ ' $\lambda \alpha \nu \tau \alpha$ instead of $\mu \nu \alpha \hat{s}$ )

- the repetition of key phrases and the parallelism in Matthew 25:19-24 are reminiscent of the same techniques in Matthew 18:23-30 and 20:1-13

- the description of the first two slaves as being faithful over

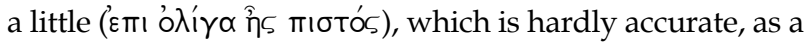
talent is hardly a little, concurs with the description of the

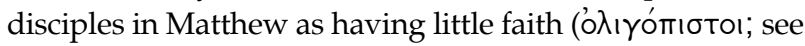
e.g. Mt 6:30; 8:26; $14: 31 ; 16: 8)$

- typically of Matthew in relating ethics to eschatology,

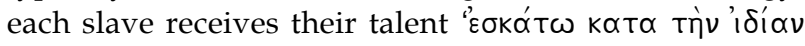

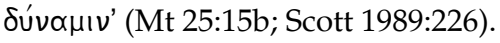

Luke's version lacks Matthew's eschatological colouring of the parable, the only eschatological aspect of the parable being its introduction in Luke 19:11 that links the parable to the Zacchaeus narrative in Luke 19:1-10, which resulted in some presuming that the long awaited parousia was approaching. Luke 19:11, however, is part of Luke's framing of the parable, that is, his redactional activity. As a result, Luke 19:11 cannot be considered as part of the version of the parable used by Luke, which only starts at Luke 19:12b (Bultmann 1963:113; Kilgallen 2008:157). ${ }^{7}$ An important facet of Luke's version is that it is more realistic than that of Matthew. Firstly, Luke's use of $\mu \nu \hat{\alpha}$ (see Lk 19:13, 16, 18, 20, 24), instead of Matthew's

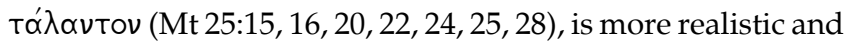
does not create the problem of Matthew 25:21 and 23 (' $\varepsilon$ mi '

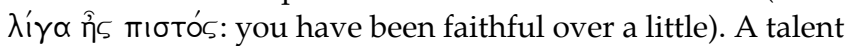
indeed was not a little. ${ }^{8}$ Secondly and more importantly, is that Luke's version contains some features that mirror the historical background, political background and socioeconomic background of $30 \mathrm{CE}$ Palestine. These features

7.Scott's (1989:222) argument, that the inclusion of Luke 19:12b and 14 in Luke's version of the parable also indicates an eschatological tendency, can also be interpreted in a different way, namely that it refers to a historical event that was known by the hearers of the parable. This possibility will be explored in what follows.

8.A talent was a silver coinage, weighted between 57 and 74 pounds, equaling 6000 denarii. One denarius was the average subsistence wage for a day laborer. A 6000 denaril 100 denarii or dras mina equaled 100 de thus represented the wage of a day laborer for between 15 and 20 years and on talent the wage for between two and three months (see Bailey 2008:398; Bouche 1981:139; Donahue 1988:107; Hultgren 2000:274; Jeremias 1972:60; Schottroff 2006:184; Scott 1989:224; Snodgrass 2008:528) include the story of a well-born man who goes to receive a kingdom, has his leadership contested by his subjects and proceeds to slaughter his opponents on his return (the socalled 'throne claimant parable'; Lk 19:12b, 14 and 27), the first two slaves being appointed over respectively ten and five cities (Lk 19:17, 19) and the description of the nobleman as being aùornpòs [harsh], taking where he did not deposit and reaping where he did not sow (Lk 19:21, 22). ${ }^{9}$ A final important aspect of Luke's version is that the third slave is not judged, but only called поипре [bad or evil]. This feature of the parable has thus far has only been emphasised by Scott (1989:22), an important aspect of Luke's structure of the parable which has not received the necessary attention from previous scholars' interpretation of the parable. ${ }^{10}$

Based on the previous discussion regarding the different versions of the parable, two points of departure will determine the interpretation of the parable that follows. Firstly, the similarity between the vocabulary and other elements of the two versions of the parable in Matthew and Luke (see e.g. McGaughy 1975:235; Scott 1989:229) proves adequate to argue that both these versions stem from Q. Luke's version is most likely the closest to the Jesus-tradition, with Matthew reworking $Q$ to fit his eschatological focus in Matthew 24-25. Luke's version of the parable fits well into what has previously been indicated as typical of Jesus the Galilean's message (see Van Eck 2009:310-321): the parable is evidence of the social stratification, patron-client relationships, the exploitative relationship between elite and nonelite and conflict and peasant resistance that formed part and parcel of 1st century Palestine as an advanced agrarian society under the control of the Roman Empire, issues addressed in almost all of Jesus' parables (see Van Eck 2009:313). The parable also fits well in the central theme of Jesus' parables, namely the nonapocalyptic kingdom of God, a transformed world, a kingdom 'that challenged the exploitative social and economic kingdoms of this world' (Borg 2006:186; see also Moxnes 1988, 2003:147-157; Van Eck 2009:315-316). The parable in Luke is not a story about God (theocentric), but a story about God's kingdom (i.e. the characters in the parable do not point to God but to the kingdom of God; see Van Eck 2009:318). ${ }^{11}$

As a result of these features of Luke's version (in addition to those discussed earlier) and serving as second point of departure, Luke's version of the parable, namely Luke 19:12b-24 and 27 (excluding Lk 19:25-26), is considered as being closer to the earliest layer of the historical Jesustradition. It will therefore be the focus of the interpretation of the parable that follows. The reason for this delineation of the parable and the question as to whether Luke's version of the

9.See in this regard the following remark of Crossan (1973:101): "It is ... obvious from the master in the parable ... that Jesus was interested in realistic rather than idealistic masters'

10.This feature of the parable will be attended to in what follows.

11.Matthew's version of the parable is clearly 'a story about God'. The setting of the 1.Matthew's version of the parable is clearly 'a story about God'. The setting of the links Matthew's version to the time between Jesus' resurrection and parousia, instructing its hearers on a specific way of acting in this intervening time. This instructing its hearers on a specific way of acting in this intervening time. This
setting of the parable makes no other reading possible than that of equating the man that goes on a journey and comes back to judge with Jesus. 
parable can be traced back the earliest layer of the historical Jesus-tradition will both be addressed subsequently.

\section{History of interpretation} Earlier interpretations

The earliest interpretations we have of the parable are the allegorical interpretations typical of early (and sometimes later) parable interpretation. Some of these interpretations focused on the minas received by the slaves as gifts, either spiritual (Bede and Maldonatus) or worldly (Aquinas and Chrysostom). The correct use of these gifts would result in receiving additional similar gifts, whilst those who do not use their gifts would lose them (see Kissinger 1979:33, 40, 43, $60)$. Others saw the received minas as the reception of the gospel, with the first slave representing the conversion of the Jews, the second slave the conversion of the Gentiles and the third the unconverted (see Snodgrass 2008:528). Another focus was the slaves as referring to teachers; the first was sent to the Jews, the second to the Gentiles and the third slave represented those teachers that did not proclaim the gospel as they should (see Snodgrass 2008:529). In these early allegorical interpretations we also find an interpretation, still popular amongst some modern parable scholars, that the man who departs refers to Jesus' ascension, his return to Jesus' parousia and the reckoning to the final judgement. A good example of this kind of interpretation is that of Calvin (see Kissinger 1979:55): in the parable, Jesus teaches the disciples that they will face troubles and hardships for a long time before they finally inherit the kingdom; it would be wrong for them to be idle during this interim, for each person is entrusted a certain office in which he may engage. At Jesus' return, all will be judged according to what they did with the offices they received.

\section{Reading the parable in its literary context as a parable of the historical Jesus}

This latter allegorical interpretation is still abundantly popular in modern parable scholarship, especially those readings that interpret the parable in its literary context. These readings, generally speaking, see the parable in Luke as a parable of the historical Jesus; they interpret the parable as a reference to Jesus' second coming and consequently see the parable as an eschatological warning. ${ }^{12} \mathrm{~A}$ few examples:

- a person is prepared for the coming of the Lord when he acts responsibly with the gifts God has bestowed on him (Groenewald 1973:223-231)

- the parable warns against an attitude that will bring about exclusion from God's kingdom (Donahue 1988:109; see also Münch 2007:240-254)

- the conduct of all servants and citizens of the kingdom of God will be made known when Christ comes to reward and punish (Lockyer 1963:305-309)

- 'in the end, all the disciples of Jesus are accountable to him' (Hultgren 2000:289)

12.'The parable depicts the time from Jesus' death and resurrection to the parousia and is directed towards the disciples to encourage kingdom living. This is the traditional and most obvious understanding of the present form of the parable (Snodgrass 2008:529).
- the master (God) expects profit (good deeds) that will be rewarded at the day of judgement (Kilgallen 2008:157164).

Another popular interpretation in modern parable scholarship is to focus less on the eschatological theme and more on stewardship. Themes that are subsequently identified in the parable related to positive stewardship are:

- faithfulness (Bailey 2008:398-409; Jülicher 1910:317; Snodgrass 2008:539-540; Stein 1981:64-65)

- watchfulness (Keach 1974:701-736; Kistemaker 1980:123)

- responsibility (Capon 1989:86; Manson 1951:249; Via 1972:119-120)

- the proper use of money (Reid 2001:203)

- or grace (Oesterley 1936:149)

- trust (Dodd 1961:61-62)

- accountability (Stiller 2005:66-75; Wenham 1989:88)

- preaching (Drury 1985:155-157).

A few scholars have also focused on some negative traits of stewardship in their reading of the parable, namely fear of failure (Donahue 1988:106-108), playing it safe (Voris 2008:101-103) and the making of excuses (Boice 1983:202207). ${ }^{13}$

\section{Reading the parable in its $\mathbf{3 0}$ CE setting}

It is interesting to note that most scholars who read the parable independent from its literary context in Luke (i.e. as a parable of the historical Jesus in a 27-30 CE context) have come to more or less the same conclusion regarding Jesus' intention with the parable. When Jesus told the parable, he had the religious leaders in mind. God's revelation had been entrusted to them, but these religious leaders, whose emphasis was on the law and the tradition, excluded certain groups from salvation and made the religion sterile. The parable repeats Jesus' concern for the Gentiles, sinners and tax collectors and should be understood as a rebuke to those religious leaders who avoided the unclean to keep the Torah pure. In these readings, the actions of the third slave refers either to the religious leaders in general (Boucher 1981:142; Hunter 1960:106-197, 1971:96-99; McGaughy 1975:235-245), the Pharisees (Cadoux (1930:106), those pious Jews who practice exclusiveness (Dodd 1961:61-62), or the scribes (Jeremias 1972:58-63). ${ }^{14}$ Perkins (1981:146-153), on the other hand, argues that the parable is directed at the disciples. Jesus told the parable to address the issue of paralysing fear in the face of their mission to follow, with the only road to success being to take the risks of the first two servants. This is the only attitude that a disciple can take. There is no 'safe'

13. Schottroff (2006:185) rightly notes that it is difficult to understand how in these interpretations (and the allegorical interpretations in the previous paragraph) Jesus can be equated with the noble man leaving and returning when the description of the noble man in the parable is taken into consideration. The problem with these interpretations is much deeper, namely the general tendency amongst parable scholars to identify the actors or characters in the parables with God or Jesus himself To read the parables from this perspective is to depict a Jesus that made theological statements and told stories about heaven. Jesus had no doctrine of God, made no theological statements and never used abstract language. In the words of Herzog: 'The parables were not earthly stories with heavenly meanings, but earthly stories ' God. The parables point to the kingdom of God (see Van Eck 2009:318).

14.According to Jeremias (1972:63), the parable in its Lukan setting has a Christological meaning. This is the result of the kerugma of the primitive church, interpreting the original parable of Jesus as a warning to the community not to become slack because of the delay of Christ's return. This, however, was not the original intent because of the
of the parable. 
position (Perkins 1981:150). Scott (1989:234), who also reads the parable in its $30 \mathrm{CE}$ context, takes a somewhat different approach. In the parable, it emerges how one goes about claiming the future. Is it claimed by preserving the precious gift or in freedom of action? The parable demands that the servant must act boldly. Some scholars, finally, read the parable not as pointing to the delay of the parousia, but in the light of God's inbreaking kingdom (Crossan 1973:119; Buttrick 2000:174; Johnson 1982:139-159; Lambrecht 1983:184-187; Weder 1984:206-207; Wohlgemut 1997:119; Wright 1996:631-639).

It is important to note that all the previous interpretations, without exception, interpret the nobleman in the parable as a positive figure, praise the actions of the first two slaves and vilify the third.

\section{Social-scientific readings of the parable}

Rohrbaugh's (1993:32-39) reading of the parable is the first social-scientific interpretation of the parable, questioning the 'alleged capitalist motif' or ethnocentristic readings of the parable 'that has been particularly dear to exegetes of our own time' (Rohrbaugh 1993:33). ${ }^{15}$ In his reading of the parable, he focuses on the salient features of peasant economics, especially the notion of limited good, the mode of production and the pattern of exchange relations amongst agrarian peasants and how the story might have been viewed by a peasant of 1st century Palestine. Limited good, according to Rohrbaugh (1993:33, in following Forster and Malina) means, in short, that the pie is limited. Peasants in the 1st century viewed all desired things (e.g. land and wealth) as in short supply (limited) as far as the peasant is concerned, with no way directly within the peasant's reach or power to increase available quantities. Thus, a larger share for one automatically meant a smaller share for someone else. Linked to this aspect of advanced agrarian societies, were the peasants' perception of production and the mode of exchange relations amongst agrarian peasants. Peasant production was primarily for use rather than exchange. Being subsistence economies, peasants did not see the purpose of labour as that of creating wealth, but simply as maintaining the family and the well-being of the village. As a result, peasants evaluated the world of persons and things in terms of use and not exchange. Therefore, for peasants it was acceptable to sell commodities

15.Regarding the abundant capitalist readings of the parable, Rohrbaugh (1993) makes the following remark: 'It should not take a great deal of thought to recognize a striking similarity remark. 'I should not take a great deal of thought to recognize a striking similarity between the parable's fundamental ideas ... and the basic thets of modern capitalism the capitalist societies of the west. Indeed, commentators twentieth centuries have genuinely reveled in the parable's seeming exhortation to venturous investment and diligent labor. It appears to be nothing less than praise for a homespun capitalism on the lips of Jesus' (Rohrbaugh 1993:33). Bailey (2008:397) is of the same opinion: 'Each of us perceives reality through the lenses of our language, culture, history, politics, economic theories, religion and military. As Westerners, one of our lenses is capitalism ... the parable of the pounds need to be liberated from the presuppositions of capitalism that perhaps have unconsciously influenced our translations and interpretations of this story'. The same critique on the capitalist reading of the parable comes from Ford (1997:35): 'This parable suffers from a pervasive misconception, the consequence of an unfortunate collusion between modern Western values, and the altogether different motives of the Gospel editors of Matthew and Luke. Taken together, however, these perspectives imbue the story's exacting master both with integrity and with the perspectives imbue the story's exacting master both with integrity and with the consequent authority accurately to evaluate his well-positioned slaves. In the judgement of nearly is parable protagonist is someone to be believed. Only Wester reader, steeped in the mores of modern capitalism, could so thoroughly miss what was the obvious to Jesus' original peasant audiences, namely, that this master's mode of operation is criminal.' in order to obtain money to buy other needed commodities; but to use money to buy commodities which one then sold again at a profit was 'unnatural'. As a result, profit making was seen as evil and socially destructive (e.g. usury and the trade in money) and rich people as evil and thieves. To gain more than one has, was to steal from others. Read from this perspective, the actions of the nobleman (laying out his money to agents, with the first two slaves pursuing and amassing new wealth) may have been good news when seen from the perspective of the elite or rich, but looked at from a peasant's perspective, it was bad news. The good news in the parable, for the peasants, would rather have been the actions of the third slave; by tying his entrusted money in a cloth he did the honourable thing, namely, protecting the money of his nobleman. By doing this, he also refrained from participating in the scheme of the nobleman to exploit (steal) from others. ${ }^{16}$ The third slave in the parable is the 'hero' (and not the first two 'thieves') and the gist of the parable is to warn those who exploit or mistreat the poor.

Taking Rohrbaugh's reading of the parable as starting point, Herzog (1994:155-168) also views the actions of the third slave as positive, characterising him as a 'whistle-blower'. According to Herzog, the setting of the parable focuses on the household of an urban elite aristocrat. These aristocratic households normally controlled several estates and villages. The wealth created by these estates and villages was harvested, stored, redistributed or monetised and exported (Herzog 1994:156). Because the head of the household could not always stay home to protect his interests, if he intended to expand his influence (e.g. travelling abroad to increase investments, initiate new investments, or build new patronclient networks) he had to make use of retainers. These retainers were not 'household slaves (oiketeia), although they may ... have been called douloi to emphasize their dependence on their patron-master' (Herzog 1994:157). In the parable, two of the three retainers (slaves) most probably made loans to peasant farmers (with interest rates that could range from $60 \%-200 \%$ ) to make it possible for these farmers to plant their crops. In essence, however, the making of these loans were not to help the farmers, but to obtain their land as collateral with possible foreclosure if the peasant farmers could not cover their incurred indebtedness. In short, to increase the wealth of their patron, they honoured him by exploiting the peasantry: 'their exploitative work sets the rules of the economic game played by an oppressive elite and an oppressed rural population' (Herzog 1994:161). The third retainer, however, describes the aristocrat for what he is: 'an exploiter who lives of the productive labor of others' (Herzog 1994:164). In the parable, this statement of the third slave exposes the codification of the world of the retainer in the households of powerful elite and to cover himself, the third slave returns to the aristocrat what is duly his. This makes the third slave the hero of the story (Herzog 1994:165-167).

16.See here also Cardenal (1982:39-40), Fortna (1995:214, 218) and Kahler (1995:171-179). According to Cardenal, the parable is 'a very ugly example ... of exploitation', Fortna describes the master as engaged in an exploitative enterprise, whilst Fortna sees the master as 'inhumanly hard', 'a blood sucker,' 'an oppressor', whilst Fortna sees the master as 'inhuma
a thief', 'a usurer,' and a 'loan shark'. 
These two readings of the parable clearly differ from the readings of the parable discussed in the previous sections. Whilst the aforementioned readings see the nobleman in the parable as a positive figure, praise the actions of the first two slaves and vilify the third, the two social-scientific readings discussed here interpret the parable in the direct opposite way; the actions of the nobleman and the first two slaves are seen as negative and that of the third slave as positive.

\section{Integrity and authenticity}

In a previous section it was concluded that Luke's version of the parable, namely Luke 19:12b-24 and 27 (excluding Lk 19:25-26), can be considered as most probably the closest to the earliest layer of the historical Jesus-tradition. This conclusion raises the following questions: why should Luke 19:11, 12a and Luke 19:25-26 be excluded and the so-called throne claimant parable be included?

Luke 19:11-12b, as argued previously, is the result of Luke's redactional activity, linking the parable to the Zacchaeusnarrative in Luke 19:1-10, which resulted in some presuming that the long awaited parousia was approaching. Luke 19:11$12 \mathrm{~b}$ can thus be dismissed as not being part of the original parable. As is common with almost all the other parables in the Synoptics, it is part of Luke's framing of the parable.

Luke 19:25 is considered by most interpreters of the parable as a secondary addition (see e.g. Crossan 1973:99; Hultgren 2000:287; Jeremias 1972:62; Weiser 1971:251-252). From a textual critical perspective, Luke 19:25 is missing in two important Greek witnesses, namely codices Bezae and Washington, as well as in some old Latin, Syriac and Coptic versions $\left(69, \mathrm{pc}, \mathrm{b}\right.$ e $\mathrm{ff}^{2}$, sy $\mathrm{sy}^{\mathrm{sc}}, \mathrm{bo}^{\mathrm{ms}}$; see $\left.\mathrm{NA}^{27}\right)$. In terms of the strategy of the parable, the third slave is reckoned with in Luke 11:24 and the opposers (of Lk 19:14) in Luke 19:27, hence repeating the pattern of Luke 19:13 (that focuses on the slaves) and Luke 19:14 (that focuses on the opposers). If Luke 19:25 (and Lk 19:26, discussed in what follows) is dismissed as either pre-Lukan or Lukan, the speech of the nobleman is not interrupted. The parable ends with the nobleman deciding on the action to be taken with his two 'opposers' in the parable, the third slave and those who did not want him to be king.

Luke 19:26 is seen by most interpreters as a 'free floating proverb', as it occurs elsewhere in the gospels (Mk 4:25; Mt 13:12, Lk 18:18; 19:26) and in the Gospel of Thomas 41 (Bultmann 1963:176; Crossan 1973:99; Davies \& Allison 1997:410; Dodd 1961:116-118; Donahue 1988:105; Herzog 1994:151; Jeremias 1972:60; Jülicher 1919:478; Lambrecht 1983:230-232; Manson 1951:248; Smith 1973:167; Via 1967:114; Weiser 1971:253; Wohlgemut 1997:106). Luke 19:26 can therefore also be omitted from the 'original' parable.

Luke 19:12, 14 and 27, the Lukan description of a well-born man who goes to receive a kingdom, has his leadership contested by his subjects and proceeds to slaughter his opponents (the so-called throne claimant parable), is seen by several scholars as a separate and original parable of Jesus about a claimant for a throne. It is seen as reflecting the historical situation in $4 \mathrm{BCE}$, when Archelaus journeyed to Rome to obtain his kingship over Judaea confirmed. At the same time, a Jewish embassy of 50 persons went to Rome in order to resist Archelaus' appointment. Nonetheless, Archelaus was appointed and when he returned to Judaea he took revenge on those that had opposed him (see Josephus J.W 2.80-100, 111; Ant. 17.208-249, 299-314). ${ }^{17}$ This independent parable was fused with the parable of the talents in either the pre-Lukan tradition or by Luke himself and with the provided setting in Luke 19:11, used by Luke allegorically to allude to the ascension of Jesus and his parousia (see e.g. Blomberg 1990:218-221; Boucher 1981:140; Crossan 1973:99; Herzog 1994:154-155; Hultgren 2000:284-285; Jeremias 1971:59; Lambrecht 1983:176; Snodgrass 2008:537; Weder 1984:195; Weiser 1971:226-272; Wenham 1984:73; Wright 1996:633).

This interpretation builds on the premise that the parable is determined by Luke 19:11, giving it an eschatological flavour. When Luke 19:11 is seen as Luke's redactional activity (as discussed previously), then Luke's version of the parable has no eschatological colouring, but mirrors the historical background, political background and socioeconomic background of $30 \mathrm{CE}$ (as mentioned before). Then, the so-called 'throne claimant parable' was in all probability part of the earliest version of the parable as told by Jesus. Moreover, this interpretation can only work if the actions of the two slaves in the parable are interpreted positively. This, however, as will be indicated in the following, is not necessarily the case.

If one takes the Archelaus narrative as being part of the parable, the parable is no longer about a man leaving, returning and reckoning (alluding to the ascension of Jesus, his parousia and judgement) and two good slaves and one bad slave. Rather, it is a story about a normalcy that was part and parcel of the 1st century world of Jesus, namely elite looking for power, power that exploits and the exploited who resist. ${ }^{18}$ Seen from this perspective, the parable is about a well-born man looking for more power, two groups of the exploited protesting in different ways, two ways of adhering to the well-born man's instruction to 'do business' with entrusted money and two reckonings. The inclusion of the Archelaus story also rounds of the parable nicely, linking Luke 19:12b with Luke 19:27.

17. According to Perkins 1981:147, the insertion in the parable does not refer to Archelaus, but to the events of how Herod the Great came to the throne Scott (1989:22), on the other hand, argues that the theme of a throne claimant was (1989:22), on the other hand, argues that the theme of a th
common enough to render historical connections unnecessary.

18.See in this regard the following important remark of Rohrbaugh (1993): The parable of the talents is 'indeed a parable and not an allegorical story. It draws upon events familiar from the real world to create an imaginary and open-ended situation ... which hearers are invited to ponder' (Rohrbaugh 1993:33). This is also the point of view of Van Eck (2009:316-317): Jesus told parables that give evidence to those elements that were common of advanced agrarian (aristocratic) societies like debt, patrons, elite using their status to coerce tenants, the existence of large estates and tenants working on large estates most probably because they lost their land through excessive taxes or debt, elite that amass wealth, which was seen as land through excessive taxes or debt, elte that amass wealth, which was seen a theft in a limited good society; elite putting money out on loan at most probably very high rates and the poor not being looked after. These stories not only assume knowledge of the Palestinian countryside under the early Roman Empire, but also reveal the ugly face of the exploitation of the peasantry by the elite so commo to advanced agrarian (aristocratic) societies. By telling these parables, Jesus most probably acknowledged the needs and frustrations of the peasants in his 1st century rural context (see Oakman 2008:118). 
Support for this reading comes from Schottroff (2006):

Luke 19:11-27 ... does not combine two independent parables about slaves and a claimant to a throne; it tells a story that is coherent in itself, about the beginning of the reign of a vassal king, his management of the administration of his kingdom, and the establishment of his power.

(Schottroff 2006:187)

Snodgrass (2008:536) and Buttrick (2000:173) are therefore not correct when they respectively state that 'throne claimant elements shift the focus of the parable and weave a second plot that causes some loss' and that the 'added material, an overdrawn theological allegory, does not fit the structure of the parable terribly well'.

In what follows, Luke 19:12b-24 and 27 will be used as the 'working parable'. Does the parable go back to the historical Jesus? This question will be attended to in a following section.

\section{How realistic is the parable?}

Previously, it was argued that the parable of the minas (Lk 19:12b-24, 27) mirrors certain historical aspects, political aspects and socioeconomic aspects that were normalcies in 30 CE Palestine. Put differently, the parable is realistic in its description of slaves being entrusted with money with which they had to trade with, slaves who made extensive profits, slaves who were appointed over cities (that many scholars see as a secondary addition to the parable; see e.g. Hultgren 2000:287) and a nobleman who took where he did not deposit and reaps where he did not sow. These aspects of the parable require further explanation if one wants to read the parable against the background of 1st century Palestine. An explanation of what these normalcies entailed will contribute significantly with regard to understanding the crux of what the parable is most probably all about.

In Luke 19:21, the third slave describes the nobleman who entrusts money to his slaves to ' $\pi \rho \propto \gamma \mu \alpha \tau \varepsilon v$ o $\sigma \sigma \theta \varepsilon$ ' [do

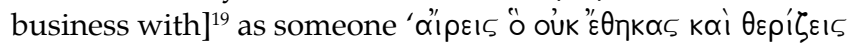

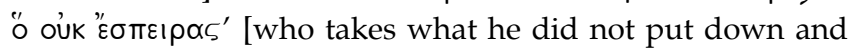
reaps what he did not sow]. To what aspect(s) of 1st century Palestinian life does this description refer to? Palestine in the 1st century was part of the Roman Empire. Rome claimed sovereignty over land and sea (its yield), the distribution of its yield and its cultivators (the peasantry). This was carried out through an exploitative tributary system consisting of land tax and poll tax. Rome ruled Palestine through native collaborators from the elite, who had the responsibility of paying the annual tribute, extracted from the peasantry, to Rome (e.g. Herod Antipas in Galilee and Archelaus in Judaea). These client kings had lavish and consumptious lifestyles and the wealth that was required to support this type of lifestyle came from the peasantry by means of a second level of tribute and taxes; the ruling elite claimed the so-called surplus of the harvest and added tribute and taxes. This left the peasantry in a situation where their level of subsistence functioned in a very narrow margin. The only

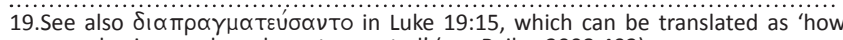
many businesses have been transacted' (see Bailey 2008:402). way to survive was to borrow from the elite and the elite were always willing to invest in loans with interest rates of up to 20\% (see Carter 2006; Fiensy 1991, 2007; Goodman 1982, 1987; Hanson \& Oakman 1998; Horsley 1993; Oakman 1986, 2008). According to Goodman (1982:426), the elite class was so excessively wealthy that they could not spend all that they had through consumption and the erection of large buildings. The elite were therefore always looking for opportunities for investment; of which the extension of credit (loans) to small farmers became an enormous source. The aim of these investments was to acquire land when repayment of debts failed. Indebted farmers were frequently enslaved and became the property of their new masters. To borrow from elite meant that the borrower became a client of a patron, that is, the peasant farmer became part of a patron-client relationship. ${ }^{20}$ Patronage took on many forms, of which one was brokerage. In brokerage, a broker functions as a mediator who gives a client access to the resources of a patron (Moxnes 1991:248).

This short description explains what is meant in the parable with the description of the nobleman and his command to his slaves. The nobleman, as part of the ruling elite, 'reaps what he did not sow' by taxing the peasantry and claiming the so-called surplus of the land and 'takes what he did not put down' in that his slaves are acting as his brokers in giving loans ('doing business') to make profit on behalf of their master.

What does it mean that the nobleman appointed the first and second slave over respectively ten and five cities? According to Llewelyn (1998:47-76), early republican Rome made use of tax-farmers to collect state revenue. These publicani collected all direct taxes on crops and pasture dues inter alia. With the demise of the Republican order, direct taxation was entrusted to the cities and local communities. This was the case in both Roman Egypt and Roman Judaea (Llewelyn 1998:74; see also Rostovtzeff 1904:101). Direct taxes were the responsibility of a government agent and only indirect taxes (e.g. custom duties, tolls, market taxes and trade taxes) were the responsibility of the publicani. The government agent, for example the procurator in Judaea or Herod Antipas in Galilee, made use of officials [conductors] in gathering the taxes, ${ }^{21}$ but the use of slaves was forbidden (Llewelyn 1998:53).

This, however, is exactly what Archelaus did. One of the accusations laid before Augustus by the embassy that protested his appointment as king was that Archelaus

20.Moxnes (1991:242) defines a patron-client relationship as follows: 'Patron client relations are social relationships between individuals based on a strong element of inequality and difference in power. The basic structure of the relationship is an exchange of different and very unequal resources. A patron has social, economic and political resources that are needed by a client.' Patron-client relationships were part and parcel of advanced agrarian societies (Moxnes 1991:248). Elites entered willingly into patron-client relationships with the poor and the peasantry. These relationships benefited the elite in terms of the accumulation of honour and status and from the side of the peasantry it enabled them to secure something more than just subsistence living. The purpose of patron-client relationships was more than just subsistence living. The purpose of patron-client relationships was Herzog 2005:55; Hanson \& Oakman 1998:72).

21.If Scott (1989:230) is correct that ๔ư ornpós in Luke 19:21 and 22 is also used to refer to government officials that are strict in their examination of accounts, it clearly links Archelaus in the parable with the gathering of taxes. See also BAGD (1957:121) links Archelaus in the parable with the gathering of taxes. See also BAGD $(1957: 121)$
that gives 'government finance inspector' as one of the possible meanings of that gives 'govís.
auotnpós. 
imposed on his subjects that 'they were to make liberal presents to himself, to his domestics and friends, and to such of his slaves as were vouchsafed the favour on being his tax gatherers' (see Josephus Ant. 17.299-314, [author's own emphasis]). And this is also exactly what Archelaus did after his appointment as etnarch [leader of the nation] on his return; the two slaves that did so well in 'doing business' with his money, are appointed over ten and five cities to gather taxes. In the words of Schottroff (2006):

In the parable the slaves make large profits with very little money: ten and five times the original sum $(19: 16,18)$. In doing so, they have proved to the satisfaction of the new king that they can form the backbone of his administration ... Now the slaves can relate in grand style what they so successfully accomplished on a small scale: exploiting people and the land to increase the wealth of their master.

(Schottroff 2006:185)

\section{A social-scientific reading of the Minas (Lk 19:12b-27, 27) The structure of the parable}

The structure of the parable is made up of five sets of 'twos'. ${ }^{22}$ In an effort to enhance his power, privilege and wealth, the nobleman does two things. He sets of with the hope of being proclaimed king ( $\operatorname{Lk} 19: 12 \mathrm{~b}$ ) and entrusts money to ten of his slaves to 'do business' ( before he leaves (Lk 19:13). These two actions of the nobleman lead to two sets of reactions in the parable; one of adhering and one of protesting. Two slaves in the parable do business with the minas they received, as expected by the nobleman (Lk 19:16, 18) and two characters protest against the actions of the nobleman. An embassy (as a character group) sets off to ask that the nobleman not be installed as king (Lk 19:14) and one slave protest against the instruction of the nobleman by not doing business with the mina he was entrusted with (Lk 19:20-21).

When the nobleman returns, two different sets of actions again take place. Firstly, the two slaves that are able to show good profits are praised and awarded for their efforts. In two scenes in the parable (Lk 19:17, 19) the first slave is awarded ten cities and the second slave five. Up to this point in the parable, there is a consistency in its strategy: two actions, two protests, two compliances and two awards. In the last set of twos, when the nobleman reckons with his two protestors, the consistency in the parable is broken down. The enemies of the nobleman are judged and killed (Lk 19:27), but the third slave is not condemned (Lk 19:22-23), only called movnp'

22. Social-scientific criticism ... studies the text as both a reflection of and a response to the social and cultural settings in which the text was produced' to determine 'the meaning(s) explicit and implicit in the text, meanings made possible and shaped by the social and cultural systems inhabited by both authors and intended audiences' (Elliott 1993:8). Social-scientific criticism approaches texts as units of meaningful discourse that express (because of their ideological dimension) certain ideas and beliefs (cultural perceptions, values and worldviews), describe social relations, behaviour and institutions and serve to motivate and direct socia behavior. As such, texts either legitimate social institutions, or serve as vehicles of behavior. As such, texts either legitimate socialifititions, or serve as vehicles of social change (Elliott 1993:49-51). Social-scientific criticism, as exegetical method, analyses texts in terms of their strategy and situation. The situation of a text refers to the social circumstances in which the text was produced (Elliott 1993:54-55) and the text's strategy, as defined by Elliott (1993.55), refers to its pragmatic and rhetorical dimension [its structure], the manner in which the text in its totality of form and content (syntactic and semantic dimensions) is designed to have specific effect upon ... [its] ... receiver(s)'. [bad or evil]. In terms of the structure of the parable thus far, the hearers of the parable would have expected that both the third slave and the embassy that protested would be judged and condemned. But then the inconsistency and surprise: the ruthless and hard man who takes what he did not put down and reaps what he did not sow, who exploits and does not stand for any opposition in what he wants to achieve, lets the third slave go, only labelling him as bad or evil. It is in this surprise in the parable that we have to look for its meaning. ${ }^{23}$

\section{Reading the parable}

When the parable is read in a $30 \mathrm{CE}$ context as a parable of Jesus the Galilean, with the help of the insights of socialscientific criticism, whilst taking the strategy of the parable seriously, the parable of the minas is not about a man who leaves and then returns to judge those who were entrusted with the 'gifts' he bestowed unto them before he left (alluding to the ascension of Jesus, his parousia and judgement). It is not a parable about two good slaves and one bad slave. The parable is about the exploitative normalcies that were part and parcel of 1st century Palestine; elite who, on a constant basis, were looking for more honour, power and privilege, elite using their power to exploit, as well as an example of the way in which the exploited could resist. In the words of Schottroff (2006:185): 'The narrative is absolute clear. It describes the economic and political structure of an exploitative kingship'.

One is tempted, like Jeremias (1972:59), to make a strong case for the probability that the parable is a copycat of the incident in 4 BCE when Archelaus went to Rome to have his kingship confirmed by Augustus, the embassy that went to Rome to contest his appointment, Archelaus' eventual appointment as etnarch and his subsequent return and revenge on those who contested his kingship. The parallels between the two stories, after all, are obvious. In the parable, as in the Archelaus story, a nobleman (Archelaus) travels to a far country (Rome) to receive a kingdom (to be installed by Augustus as a vassal king). An embassy of 50 citizens went to Rome to ask that the nobleman should not reign over them (the plead of the Jewish embassy before Augustus), the nobleman receives the kingdom (Archelaus is installed as etnarch), returns and appoints (as aúotnpós) two of his slaves over some of the cities placed under his governance (e.g. Stratos Tower, Sebaste, Joppe and Jerusalem; see Josephus Ant. 2.315-323) and finally killed those who did not want him to reign over them. ${ }^{24}$

As argued previously, in terms of its strategy, the parable cannot portray its core purpose without the throne claimant story to make its point. One can argue that it is unnecessary to see the parable as a direct reference to the Archelaus story.

23. From this description of the strategy of the parable, it is clear that the parable cannot do without the throne claimant story, whether it refers to Archelaus or not. As such, the throne claimant story cannot be seen as a later addition that is unnecessary for the structure of the parable itself (see e.g. Hultgren 2000:285).

24.Josephus has no direct reference to this aspect of the parable. He, however, states that 'Archelaus took possession of his ethnarchy, and used not the Jews only, but the Samaritans also, barbarously; and this out of his resentment of their old quarrels with him' (Josephus J W. 2,311, [author's own emphasis]). 
The reason being, that what is 'described [in the parable] is not a particular, individual historical event, but a structure' (Schottroff 2006:185); therefore, Jesus may or may not have made use of the Archelaus story to make this point, notwithstanding the obvious parallels. In other words, the parable does not merely want to focus on the events that occurred in $4 \mathrm{BCE}$, but rather on the simple normalcy of 1st century Palestinian life, namely the economic and political structure of exploitative kingship (Schottroff 2006:185). Put differently: one of the points that the parable wants to make is about the way in which the elite exploited the nonelite. The point of departure taken here is that Jesus, to make his point, most probably made use of the Archelaus story as an example of the exploitation by the elite.

The iniquities that the embassy accused Archelaus of before Augustus, after all, were exactly the same as those the nonelite (peasantry) were experiencing, namely exploitative and excessive taxation and tributes (including the taking of the so-called surplus of the harvest) to fund inter alia the lavish and consumptious lifestyles of the elite and loans at high rates. The aim of these loans was acquiring land when repayment of debts failed, thus creating large estates which in turn lead to a commercialised economy. ${ }^{25}$ According to Josephus (Ant. 17.299-314), this is exactly what Archelaus did after the death of Herod the Great: he destroyed the Jews, many of them perishing because of his adorning of certain cities. He filled the nation with the utmost degree of poverty, confiscated estates and besides the annual impositions that he laid on everyone, he demanded liberal presents to himself, his domestics and friends and treated many inhumanly.

This, then, is the first point the parable wants to make; the elite are exploiting the nonelite. The elite are like the nobleman and his two slaves (Rohrbaugh 1993:32-39). This is what the kingdom of Caesar looks like.

The second and main point of the parable lies in its surprise; both the embassy and the third slave opposed the nobleman, but only those who did not want the nobleman to be king are condemned. Why? Because in a situation (like 1st century Palestine) where the relation between empire and subjected people is one of power and all matters of importance are in the hands of the elite, with the peasantry having no legitimate channel for political participation (see Horsley 1993:5, 11; Fiensy 2007:34), there are two ways to protest: the wrong way and the correct way.

In Luke 19:12b, the man who journeys to a far country is

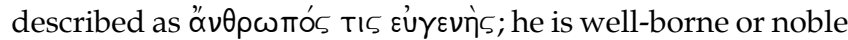
from birth. He is thus a person with ascribed honour. In the 1st century Mediterranean world, ascribed honour happened

25.This situation of the peasantry in 1st century Palestine is aptly described by Herzog (1994:206) as follows: 'The peasant village in Palestine during the early decades of the first century was under increasing stress. The cumulative effects of Herodian rule, combined with the rigors of Roman colonialism and the demands of the Temple hierarchy, had taken their toll. The monetization and commercialization of the local economy had led to increasingly predatory relationships between elites and peasants ... there is evidence for rising debt and defaults on loans; accompanied by the hostile takeover of peasant small-holdings and the reduction of peasants to more dependent economic statuses. These practices can be traced of peasants to more dependent economic statuses. These practices can be traced
back to the fact that elites made loans to peasants and held their land as collateral'. passively through birth (e.g. Archelaus was the son of Herod the Great and thus had ascribed honour). When honour is ascribed, according to Malina (1986:82), 'it is bestowed on someone by a notable person of power, such as a king or governor'. More importantly, 'the powerful one ascribing the honor has the sanction of power to make the grant of honor stick' (Malina 1986:83) and, of course, the power to annul a status of honour. If one sees the nobleman in the parable as Archelaus, this means that Archelaus went to Rome to have his ascribed honour sanctioned by Augustus. He also, however, sought acquired honour ${ }^{26}$ in his bid to receive the kingship over the territories that belonged to his father Herod the Great rather than his brothers Antipas or Philip.

Important to remember here is that in the 1st century Mediterranean world, ascribed honour was like wealth (it resembled inherited wealth) and acquired honour was like wealth obtained through one's efforts (Malina \& Neyrey 1991:28). Moreover, in 1st century Palestine 'rich' or 'wealthy' as a rule meant 'avaricious, greedy,' whilst 'poor' referred to 'persons scarcely able to maintain their honour or dignity' (Malina 1987:355; see also Rohrbaugh 1993:34-35). Traditional peasant societies (like that of the 1st century Mediterranean) perceived all resources in terms of 'limited good' and therefore saw wealthy persons as 'thieves', who had benefited at the expense of the poor (Malina 1981:71-93, 1987:363); therefore, a poor person was someone who could not maintain his inherited status as a result of circumstances that befell him and his family (like debt). At the same time, the rich person was one who was able to maintain his status. ${ }^{27}$ The terms rich and poor in 1st century Palestine, therefore, were political before they were economic (Rohrbaugh (1993:35). To be rich was to have the power to maintain what one had or even to increase it (Malina 1987:356-361).

When the embassy then consequently contested Archelaus' appointment as king, they in fact contested his honour; the most pivotal value in the 1st century eastern Mediterranean world. Discursively, they contested his power to maintain and increase his wealth and status. In essence, they played a political game in a world in which they had no legitimate channel for political participation, ultimately receiving the customary penalty dished out by the elite in cases like this. ${ }^{28}$ This clearly, according to the parable, was evidently not the way to protest.

26. Acquired honour 'is honor actively sought and achieved, most often at the expense of one's equals in the social context of challenge and riposte' (Malina \& Neyrey 1991:28).

27.According to Hollenbach (1987:57-58), this does not mean that the terms poor and rich in the 1st century Mediterranean world did not also have some economic content. In oppressive aristocratic-peasant societies, in which peasants are dominated and exploited by aristocrats, peasants as such are the poor and the aristocrats as such are the rich. The poor and the rich, therefore, were also permanent groups within society, at least in economic-political terms (Hollenbach 1987:58).

28.See, for example, the messianic movements of Judas son of Hezekiah (4 BCE), Simon (4 BCE) and Athronges (4-2 BCE; Josephus J.W 2.55-65). The participants in these messianic movements were primarily peasants with the goal to overthrow the Herodian and Roman domination and to restore the traditional ideals for a free and egalitarian society (see Horsley \& Hanson 1985:111-127). These movements and egalitarian society (see Horsley \& Hanson 1985:111-127). These movements
were all subdued in a violent way. The parallels between these movements and the embassy in the parable are clear. The embassy also consisted of peasants (nonelite), hoping to attain dissolution of kingly government, and wanting to live by

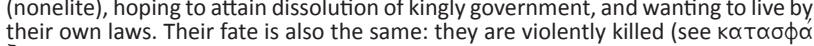

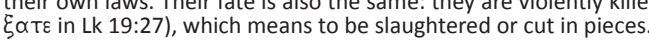


But what would be the appropriate way to protest? How can nonelites negotiate a world of material domination that appropriate their agricultural production and labour by excessive taxation? One approach is to proceed like the first two slaves, legitimating the domination of the elite. Alternatively one can, like the embassy, try to play the political game without any legitimation and subsequently carry the consequences. Or one can act like the third slave, a way of protest that Scott (1985:xvi) has called the 'hidden transcript' or 'the weapons of the weak'.

According to Scott (1977:12-16), the peasantry in the time of Jesus, although they had no legitimate way for protest, could and did, resist. The forms of their resistance were called the 'hidden transcript' (vis-à-vis the public transcript of events controlled by the rulers). This hidden transcript was a discourse that took place 'offstage', it captured 'what the oppressed say to each other and distills what they really think about their rulers but are too intimidated to express openly' (Scott 1990:18). This, however, does not mean that the hidden transcript was never expressed in public. Indeed it was, as 'weapons of the weak' in the form of inter alia encoded forms of speech (Scott 1990:19), 'a disguised, ambiguous, and coded form of speech dedicated to maintaining the hidden transcript of resistance while leaving a public transcript that is in no way actionable' (Herzog 2005:189).

\section{This is also the point of view of Carter (2006):}

\begin{abstract}
More often, since direct confrontations that are violent or defiant provoke harsh retaliation [like what happened to the embassy in the parable], protests among dominated groups are hidden or 'offstage'. Apparent compliant behavior can be ambiguous. Often protest is disguised, calculated and self-protective. It may comprise of telling stories that offer an alternative or counterideology to negate the elite's dominant ideology and to assert the dignity or equality of nonelites. It may employ coded talk ... or double talk that seems to submit to elites ... but contains, for those with ears to hear, a subversive message.
\end{abstract}

(Carter 2006:11-12)

This is how the excuse of the third slave can be understood. As correctly interpreted by Rohrbaugh (1993:33-34), the nobleman is a thief in the eyes of the third slave. He does not want any part in the exploitation of the peasantry. So what does he do? Firstly, he ties the mina in a cloth to protect the existing share of the owner, 'exactly what in the peasant view an honorable person should do' (Rohrbaugh 1993:36). Secondly, when confronted by his master, he does not characterise his master as a hard man to justify his fear and consequent inactivity with the mina. He rather employs the 'weapons of the weak': 'I knew I had to be careful, and I have been' (Rohrbaugh 1993:37). How would the nobleman have heard this? Most probably in the sense of 'Master, I have so much respect for you (I am honouring you), that I did not want to take a chance with your money. I did what I thought was the honourable thing to do, that is, to protect what belongs to you'. But what did the peasants, who most probably were part of the audience when Jesus told the parable, hear? Most probably: 'You are a thief, and I am not willing to be part of what you are doing!' And what did the nobleman do? As he knew that the social control and power he enjoyed was built on fear and that this lead to the action of the third slave, the slave's action in a sense was a result of his (the master's) own doing. Nonetheless, the slave acted responsibly. He was a 'bad slave', compared to the other two. But yet he respected (honoured) his master, although he made no profit. Consequently, the master let him go with only a label around his neck.

When read from this perspective, the parable of Jesus in itself is a 'hidden transcript'. Perceived from the elite's point of view, it tells a story of honour, power and legitimated judgement. This is how the elite would have interpreted it. But for the peasants it had a different meaning; this is the way to protest. 'Honour' those that exploit you, without taking part in their exploitation. To confront those that exploit directly will not work. Rather be 'as sly as a snake and as simple as a dove' (Mt 10:16b//GThom 39:3).

\section{Conclusion}

The question regarding the authenticity of the parable can now be answered. In the parable, Jesus condemns the master's viewpoint (Rohrbaugh 1993:38) and by doing this he criticises the use of honour to enhance power and privilege, class, status and wealth and the economic exploitation of the peasantry by the ruling elite. These ideas contained in the parable are incontestable his and are paralleled in some of the other parables that can be traced back to the earliest layer of the historical Jesus (e.g. Lk 12:17-20//GThom 63:1-3; Lk 16:19-26; Mt 20:1-16). Jesus' condemnation of the rich, his siding with the poor and critique regarding honour and status are also attested in several saying of Jesus that pass the criteria of early, multiple and independent attestation (see e.g. Q 6:20//GThom 54; Q 6:21//GThom 69:2; Mk 12:3839/ / Mt 23:5-7//Lk 11:42//Lk 20:45-46). Several sayings of Jesus that pass the criteria of early, multiple and independent attestation concur with the viewpoint of the third slave, who did not partake in the exploitation of others by loaning money and taking interest (i.e. generalised reciprocity; see e.g. Q 6:30//GThom 95:1-2; Lk 6:35; Q 6:35b//GThom 95:1-2). Generalised reciprocity, according to the opinion of several historical Jesus scholars, was one of the core values in Jesus' teaching. ${ }^{29}$ Several of Jesus' parables also advocate general reciprocity (see e.g. Lk 10:30-35; Lk 11:5-8; Q 14:16-24// GThom 64:1-12). The gist of the parable is clearly connected to these values.

\section{References}

Aland, B., Aland, A., Karavidopoulos, C.M., Martini, M. \& Metzger, B.M. (eds.), 1994, Greek-English New Testament, 27th edn., Deutsche Bibelgesellschaft, Stuttgart.

Arndt, W.F. \& Gingrich, F.W. (eds.), A Greek-English lexicon of the New Testament and other early Christian literature, The University of Chicago Press, Chicago.

Bailey, K.E., 2008, Jesus through Middle Eastern eyes: Cultural studies in the gospels, IVP Academic, Downers Grove.

29.For Jesus, God's rule was a power opposed to the social order established in Rome (Oakman 2008:105). Jesus made use of kinship religion and kinship economy to address the exploitative political economy and political religion of Rome. In Jesus' parables he favoured a fictive family in which relations were modeled on those parables he favoured a fictive family in which relations were modeled on those
of close kin, with exchanges taking place through arrangements of generalised reciprocity, taking no account of exchanges or debt (Oakman 2008:105). 
Blomberg, C.L., 1990, Interpreting the parables, InterVarsity Press, Downers Grove. Boice, J.M., 1983, The parables of Jesus, Moody Press, Chicago.

Borg, M.J., 2006, Jesus: Uncovering the life, teachings, and relevance of a religious revolutionary, HarperCollins, New York.

Boucher, M.I., 1981, The parables, Michael Glazier Inc., Wilmington (New Testament Message 7).

Bultmann, R., 1963, History of the synoptic tradition, Blackwell, Oxford.

Buttrick, D., 2000, Speaking parables: A homiletical guide, Westminster John Knox Press, Louisville.

Cadoux, A.T., 1930, The parables of Jesus: Their art and use, James Clarke, London.

Capon, R.F., 1989, The parables of judgment, William B. Eerdmans Publishing Company, Grand Rapids.

Cardenal, E. (ed.), 1982, The gospel in Solentiname, vol. 4, Maryknoll, Orbis Books.

Carter, W., 2006, The Roman Empire and the New Testament: An essential guide, Abingdon Press, Nashville.

Crossan, J.D., 1973, In parables: The challenge of the historical Jesus, Harper \& Row, New York.

Davies, W.D. \& Allison, D.C., 1997, A critical and exegetical commentary on the gospel according to Saint Matthew, 3 vols., T\&T Clark, Edinburgh (ICC)

Dodd, C.H., 1961, The parables of the kingdom, Charles Scribner's Sons, New York.

Donahue, J.R., 1988, The gospel in parable: Metaphor, narrative and theology in the Synoptic gospels, Fortress Press, Philadelphia.

Drury, J., 1985, The parables in the Gospels: History and allegory, New York, Crossroads.

Elliott, J.H., 1993, What is social-scientific criticism?, Fortress Press, Minneapolis (Guides to Biblical Scholarship).

Fiensy, D., 1991, The social history of Palestine in the Herodian period: The land is mine, Edwin Mellen Press, New York.

Fiensy, D., 2007, Jesus the Galilean: Soundings in a first century life, Gorgias Press, Piscataway.

Ford, R.Q., 1997, The parables of Jesus: Recovering the art of listening, Fortress Press, Minneapolis.

Fortna, R.T., 1995, 'Reading Jesus' parable of the talents through underclass eyes', Forum 8, 211-228.

Funk, R.W., Scott, B.B. \& Butts, J.R., 1988, The parables of Jesus: Red letter edition: The Jesus Seminar, Polebridge Press, Sonoma.

Funk, R.W., Hoover, R.W. \& The Jesus Seminar, 1993, The five gospels: The search for the authentic words of Jesus, Macmillan, New York.

Goodman, M., 1982, 'The first Jewish revolt: Social conflict and the problem of debt', Journal of Jewish Studies 33, 402-429.

Goodman, M., 1987, The ruling class of Judaea, Cambridge University Press, Cambridge.

Groenewald, E.P., 1973, In gelykenisse het Hy geleer, N.G. Kerk-Uitgewers, Kaapstad.

Hanson, K.C. \& Oakman, D.E., 1998, Palestine in the time of Jesus: Social structures and social conflicts, Fortress Press, Minneapolis.

Herzog, W.R., 1994, Parables as subversive speech: Jesus as pedagogue of the oppressed, Westminster, Louisville.

Herzog, W.R., 2005, Prophet and teacher: An introduction to the historical Jesus, Westminister John Knox Press, Louisville.

Hollenbach, P., 1987, 'Defining rich and poor using the social sciences', in K. Richards (ed.), SBL 1987 Seminar Papers, pp. 50-63, Scolars Press, Atlanta.

Horsley, R.A., 1993, Jesus and the spiral of violence: Popular Jewish resistance in Roman Palestine, Harper \& Row, San Francisco.

Horsley, R.A. \& Hanson, J.S., 1985, Bandits, prophets and messiahs: Popula movements in the time of Jesus, Winston, Minneapolis.

Hultgren, A.J., 2000, The parables of Jesus: A commentary, William B. Eerdmans Publishing Company, Grand Rapids.

Hunter, A.M., 1960, Interpreting the parables, SCM Press Ltd, London.

Hunter, A.M., 1971. The parables: Then \& now, SCM Press Ltd, London.

Jeremias, J., 1972, The parables of Jesus, Charles Scribner's Sons, New York.

Johnson, L.T., 1982, 'The Lukan kingship parable (Lk. 19:11-27)', Novum Testamentum 24, 139-159. doi:10.2307/1560555

Jülicher, A., 1910, Die Gleichnisreden Jesu, Mohr, Tübingen.

Kahler, C., 1995, Jesu Gleichnisse als Poesie und Therapie: Versuch eines intergrativen Zugangs sum kommunikativen Aspekt von Gleichnisse Jesu, Tubingen, Pau Siebeck.

Keach, B., 1974, Exposition of the parables in the Bible, Kregel Publications, Grand Rapids.

Kilgallen, J.J., 2008, Twenty parables of Jesus in the gospel of Luke, Editrice Pontificio Instituto Biblico, Rome.

Kissinger, W.S., 1979, The parables of Jesus: A history of interpretation and bibliography, The Scarecrow Press, Metuchen.

Kistemaker, S.J., 1980, The parables: Understanding the stories Jesus told, Baker Books, Grand Rapids.

Kloppenborg, J.S., 1998, Q parallels: Synopsis, critical notes \& concordance, Polebridge Press, Sonoma.

Lambrecht, J., 1970, 'The parousia discourse', in M. Didier (ed.), L'évangile selon Marc pp. 308-342, Louvain University Press, Louvain.

Lambrecht, J., 1983, Once more astonished: The parables of Jesus, New York, Crossroad.
Llewelyn, S.R., 1998, 'Taxation', in S.R. Llewelyn (ed.), New documents illustrating early Christianity: A review of the Greek inscription and papyri (Published 198485), pp. 47-105, William B. Eerdmans Publishing Company, Grand Rapids.

Lockyer, H., 1963, All the parables of the Bible, Zondervan, Grand Rapids.

Malina, B.J., 1981, The New Testament world: Insights from cultural anthropology, John Knox Press, Atlanta.

Malina, B.J., 1986, Christian origins and cultural anthropology: Practical models for biblical interpretation, John Knox, Atlanta.

Malina, B.J., 1987, 'Wealth and poverty in the New Testament and its world' Interpretation 41, 354-367.

Malina, B.J. \& Neyrey, J.H., 1991, 'Honor and shame in Luke-Acts: Pivotal values of the Mediterranean world', in J.H. Neyrey (ed.), The social world of Luke-Acts: Models for interpretation, pp. 25-66, Hendrickson Publishers, Peabody.

Manson, T.W., 1951, The teaching of Jesus, Cambridge University Press, Cambridge.

McGaughy, L.C., 1975, 'Fear of Yahweh and the mission of Judaism: A postexilic maxim and its early Christian expansion in the parable of the talents', Journal of Biblical Literature 94, 235-245. doi:10.2307/3265732

Moxnes, H., 1988, The economy of the kingdom: Social conflict and economic relations in Luke's gospel, Wipf \& Stock, Eugene.

Moxnes, H., 1991, 'Patron-client relations and the new community in Luke-Acts', in J.H. Neyrey (ed.), The social world of Luke-Acts: Models for interpretation, pp. 241-268, Hendrickson, Peabody.

Moxnes, H., 2003, Putting Jesus in his place: A radical vision of household and kingdom, Westminster John Knox Press, Louisville.

Münch, C., 2007, 'Gewinnen oder Verlieren (Von den anvertrauten Geldern)', in R. Zimmermann (Hrsg.), Kompendium der Gleichnisse, pp. 240-254, Gütersloher Verlagshaus, Munich.

Oakman, D.E., 1986, Jesus and the economic questions of his day, Edwin Mellen Press, New York.

Oakman, D.E., 2008, Jesus and the peasants, Cascade Books, Eugene (Matrix: The Bible in Mediterranean context).

Oesterley, W.O.E., 1936, The gospel parables in the light of their Jewish background, SPCK, London.

Perkins, P., 1981, Hearing the parables of Jesus, Paulist Press, New York.

Reid, B.E., 2001, Parables for preachers: The gospel of Matthew, The Liturgical Press, Collegeville.

Rohrbaugh, R.L., 1993, 'A peasant reading of the talents/pounds: A text of terror', Biblical Theological Bulletin 23, 32-39. doi:10.1177/014610799302300105

Rostovtzeff, M.I., 1904, Geschichte der Staatpracht in der römischen Kaizerzeit bis Diokletian, in Philologus, Supplementumband 9.

Scott, B.B., 1989, Hear then the parable: A commentary on the parables of Jesus, Fortress Press, Minneapolis.

Scott, J.C., 1977, 'Protest and profanation', Theory and Society 4, 1-21.

Scott, J.C., 1985, Weapons of the weak: Everyday forms of peasant resistance, Yale University Press, New Haven.

Scott, .J.C., 1990, Domination and the arts of resistance: Hidden transcripts, Yale University Press, New Haven.

Schottroff, L., 2006, The parables of Jesus, transl. L.M. Maloney, Fortress Press, Minneapolis.

Smith, B.T.D., 1937, The parables of the synoptic Gospels: A critical study, Cambridge University Press, Cambridge.

Snodgrass, K.R., 2008, Stories with intent: A comprehensive guide to the parables of Jesus, William B. Eerdmans Publishing House, Grand Rapids.

Stein, R.H., 1981, An introduction to the parables of Jesus, The Westminster Press, Philadelphia.

Stiller, B.C., 2005, Preaching parables to postmoderns, Fortress Press, Minneapolis.

Van Eck, E., 2009, 'Interpreting the parables of the Galilean Jesus: A social-scientific approach', HTS Teologiese Studies/Theological Studies 65(1), Art. \#308, 12 pages. doi:10.4102v65i1.308.

Via, D.O., 1972, The parables: Their literary and existential dimension, Fortress Press, Philadelphia.

Voris, S.J., 2008, Preaching parables: A metaphorical interfaith approach, Paulist Press, New York.

Weder, H., 1984, Die Gleichnisreden Jesus als Metaphern: Traditions- und redaktionsgeschichtliche Analysen und Interpretationen, Göttingen, Vandenhoeck \& Ruprecht.

Weiser, A., 1971, Die Knechtsgleichnisse der synoptichen Evangelien, Munich, Kösel (SANT' 29).

Wenham, D. (ed.), 1984, The rediscovery of Jesus' eschatological discourse, Journal for the study of the Old Testament, Almond Press, Sheffield.

Wenham, D., 1989, The parables of Jesus: Pictures of a revolution, London, Hodder \& Stoughton (The Jesus Library).

Whiston, W. (transl.), 1987, The complete works of Josephus: Flavius Josephus, Krege Publications, Grand Rapids.

Wohlgemut. J.R., 1997, 'Entrusted money (Matt. 25:14-28)', in V.G. Shillington (ed.) Jesus and his parables: Interpreting the parables of Jesus today, pp. 103-120, T\& Clark, Edinburgh.

Wright, N.T., 1996, Jesus and the victory of God, Fortress Press, Minneapolis (Christian origins and the question of God, vol. 2).

Young, B.H., 1989, Jesus and his Jewish parables: Rediscovering the roots of Jesus' teaching, Paulist Press, New York. 